This item was submitted to Loughborough's Research Repository by the author.

Items in Figshare are protected by copyright, with all rights reserved, unless otherwise indicated.

\title{
Reading the present through the past: A critical Introduction
}

PLEASE CITE THE PUBLISHED VERSION

https://doi.org/10.1057/978-1-137-55027-9

PUBLISHER

Palgrave

VERSION

AM (Accepted Manuscript)

PUBLISHER STATEMENT

This extract is taken from the author's original manuscript and has not been edited. The definitive, published, version of record is available here: doi.org/10.1057/978-1-137-55027-9

\section{LICENCE}

CC BY-NC-ND 4.0

\section{REPOSITORY RECORD}

Belfiore, Ele, and Lisanne Gibson. 2020. "Reading the Present Through the Past: A Critical Introduction". figshare. https://hdl.handle.net/2134/12008796.v1. 


\section{Chapter One}

Reading the present through the past: A critical introduction

\section{Eleonora Belfiore and Lisanne Gibson}

\section{Introduction: Reading the present through the past}

This introduction contextualises the key themes explored in this edited collection participation, values and governance - against the backdrop of current academic debates on cultural policy. We flesh out the broader methodological and theoretical standpoints from which the collection originates, expounding the contribution that an historical perspective can offer to understanding contemporary debates on politics and policy. This collection of essays originates from a 'package' of work on 'Histories' in a large funded project on 'Understanding Everyday Participation - Articulating Cultural Values' (UEP) ${ }^{1}$. As part of the broader objectives of the UEP project, this collection of essays proposes a radical re-evaluation of the relationship between participation and cultural value. The essays collected in this volume represent the project team's contribution to the development of an in-depth historical understanding of the development of definitions, assumptions and beliefs around the nature and value of cultural participation, its place in contemporary cultural governance and exploitation in local socio-economic development strategies. In this respect, this collection brings a novel critical perspective to current policy, practice and scholarly debates on the connections between culture, place-making and the creative economy.

With respect to its geographical scope, the essays in the collection all focus on England and different localities within the country, and to the UK cultural policy context. The reason for this specific focus lies in the fact that the historical explorations presented in this volume

\footnotetext{
${ }^{1}$ This work was supported by the Arts and Humanities Research Council through Connected Communities Large Project funding for 'Understanding Everyday Participation: Articulating Cultural Values', 2012-2018, $\mathrm{AH} / \mathrm{J} 005401 / 1$.
} 
are connected and complementary to empirical data gathering and ethnographic fieldwork conducted as part of the UEP project. This was focused on the comparative exploration of four different English 'cultural ecosystems' ${ }^{2}$ selected for their differing patterns of funding and participation levels (Manchester/Salford, Gateshead, Peterborough and Dartmoor) ${ }^{3}$. Whilst the specificity of place is central to the analysis offered, we suggest a wider relevance and applicability of the broader point the collection makes about the importance, for cultural policy analysis, of recognising the centrality of the inter-relations between place, space, culture, local practices and policy-making. We hope the volume might inspire others to extend to and test our arguments in other geo-cultural settings.

Orthodox models of the creative economy and ensuing cultural policy models are based on a narrow definition of cultural participation: one that captures formal engagement with traditional cultural institutions, such as museums and galleries, but overlooks other activities, for instance community festivals and hobbies (Miles and Gibson 2016). This frame, founded historically on 'deficit' based assumptions of the logics for state cultural support (Miles and Sullivan 2012), misses opportunities to understand a wider and more representative variety of forms of participation and their (positive and negative) consequences. The essays in this collection are part of the project's wider exploration of the meanings and the stakes that attach to ordinary, everyday participation (Miles and Gibson 2016; 2017).

Beyond the confines of this project, though, this collection fulfils an important need for

\footnotetext{
2 In the context of the wider project, we define cultural ecosystems as 'a historically wrought, physically situated assembly of formal and informal cultural resources, participation contexts, practices and communities, which reflect the interplay of local structures of investment, supply and demand, and as such constitute distinct economies of participation'(Miles and Gibson 2016: 153).

3 The UEP project also included a work package focusing on cultural participation in two Scottish ecosystems, Aberdeenshire and the Western Islands, which was supported by additional financial support by Creative Scotland. This strand of work is not discussed in detail here, but Miles and Ebrey (2017) is a good introduction to this part of the project.
} 
researchers and practitioners in the fields of cultural policy, arts management, heritage, museum, theatre and leisure studies in providing much needed historical insight that sheds light on contemporary issues of cultural value and governance which are of great topicality. A number of high-profile research initiatives in this area have been a feature of research in the arts and humanities in England especially since 2014, notably the Arts and Humanities Research Council's Cultural Value Project (Crossick and Kaszynska 2016), the Warwick Commission on the Future of Cultural Value (Neelands et al. 2015), and Arts Council England's (ACE) dedicated work on cultural value and its measurement resulting, for instance, in reports such as 'The Value of Arts and Culture to People and Society' (2014) and 'Understanding the Value and Impact of Cultural Experiences' (2014). However, none of these initiatives adopt the distinctive approach of this collection, which is to illuminate contemporary policy issues through the investigation of their historical roots. The originality and value of this critical-historical approach is the disciplinary and intellectual significance of the chapters in this book.

At the core of this edited collection is the conviction that by creating new understandings of the relationships between everyday participation and cultural value, it becomes possible to reveal evidence of hidden assets and resources that can be mobilised to promote better identification and more equitable resourcing of cultural opportunities, generate well-being and contribute to the development of creative local economies. Approaching participation as an historically and spatially situated phenomenon, and articulating the effects of heritage, context and place by historicizing and deconstructing present-day understandings of participation and cultural value is central to this endeavour, and has the potential to open up new avenues of research in this area. This edited collection, thus, represents both an original contribution to scholarship and an intervention in more practice-oriented debates on creative 
approaches to community engagement, place-based development and regeneration strategies as well as policy formation.

Whilst it speaks to live debates in a number of germane fields of enquiry, the key intellectual location of the volume and its main scholarly contribution is within the field of cultural policy studies. Indeed, Histories of Cultural Participation, Values and Governance is the first integrated, critical-historical examination of the terms, narratives and assumptions constructing present day notions of participation and value, and the relations between them, from the perspective of cultural policy-making. The book is organised via two inter-related thematic histories, which correspond to the two sections into which the book is divided. Part One's chapters focus on the ways in which discourses of cultural participation and value have been developed and mobilised historically and, in turn, the effects of these discursive coordinates on the development of cultural institutions and practices. The point of departure for chapters in Part Two is the ways in which cultural policies have been tools to manage populations in various different ways. In all cases, chapters interrogate the ways in which the 'problem of cultural policy', the 'politics of cultural value', and the 'problem of participation' are the product of long run histories. Often these back stories are not acknowledged in debates about cultural policy, which therefore can become circular and self-referential. As demonstrated by the historical research presented in each of these chapters, providing the long view allows a fresh perspective on these ongoing discussions which enables us to square the circle, providing new and original positions on the utility and effects of cultural participation, policy and practice and new articulations and understanding of long-debated policy 'challenges'.

\subsection{Political discourses of participation and value}


The chapters in Part One trace the long-run intellectual history of cultural participation, examining its links with ideas of civic engagement, community wellbeing, and prosperity. They explore how the attachment of certain types of participation to particular forms of value became embedded in and reproduced by institutions and policy. This theme also encompasses the examination of shifting treatments and representations of the 'everyday', exploring the role of commonplace practices and associational life in defining cultures, communities and relations of power and value, conceptions of time use and demarcations between work and leisure, and the commercialisation and privatisation of culture. The significance of the historical investigation of these ideas around participation and healthy communities and polities lies in the importance they retain in what Raymond Williams (1990[1958]: xiii) famously called 'our modern structure of meanings'. It is precisely this connection, and the way it has driven the institutionalisation of cultural values and authority in policymaking and arts funding bodies and their practices in the $20^{\text {th }}$ century that forms the object of enquiry of this section of the book. In the words of Bronowski and Mazklisch (1960: xii), '[i]deas are not dead thoughts, even when they are not contemporary; for they remain steps in the evolution of contemporary ideas'.

The first part of this edited volume collectively offers an historical excursus of ideas around cultural participation and its interconnections to local and civic values, and community development. The exploration of these ideas' legacy is woven through the book via a number of examples and case studies which begin with the eighteenth century English theatrical experience, and moves through a number of case studies that stretch to the present day. Collectively, their scholarly contribution to is to expose and explore the origin of the normative conceptions of desirable cultural participation which are at the heart of the administrative machinery for the promotion of culture and the public's access to it, and the driving ideals 
behind much of contemporary audience development and 'engagement' work within publicly funded cultural institutions.

The historical excursus begins with an exploration of eighteenth century English theatrical experience and its regulation in Chapter 2. Here, Jane Milling's chapter examines eighteenthcentury modes of cultural participation through three examples: John Dennis's The Usefulness of the Stage (1698), the aftermaths of the Stage Licensing Act of 1737, and the Chinese Festival theatre riots of 1755 . Through these illustrations, the chapter exposes the complexity of the theatrical experience and the multiple stakes of cultural participation in a particular historical moment and geographical location, and it posits that the insights thus offered represent a useful problematization of the overly simplistic rhetoric of contemporary cultural policy on cultural participation (Milling 2019).

Chapter 3 takes us forward into the nineteenth century via Felicity James' account of the history of Peterborough Museum, founded in 1871 as the Peterborough Natural History Society and Field Club as it emerged from a close scrutiny of the minute books of the Society. The minute books offers a precious insight into ways in which its values and beliefs about the social functions of participation in culture were developed and articulated, against the backdrop of wider contemporary events in national culture, represented, for example, by the diffusion of Matthew Arnold's writing - whose enduring influence on British cultural politics and policy is widely recognised (Belfiore and Bennett 2008; Bennett 2005). By adopting an explicit focus on the local and the provincial, James' chapter enriches our understanding of the nineteenth century roots of contemporary attitudes to the arts and culture and their cultivation, by exposing the ways in which these have been influenced by already existing forms of sociability and cultural practices that date back to the previous century (James 2019). 
The last two chapters bring us progressively closer to the present-time: in Chapter 4, Belfiore focuses her analysis on the momentous period that saw the establishment of the Arts Council of Great Britain from the ashes of CEMA (the Council for the Encouragement of Music and the Arts) following the end of the Second World War. In particular, the chapter throws light on the vigorous debates that had been already taking place around that time among British cultural leaders, politicians and educators on the vision that should guide the peacetime body for the financial support and development of the arts and culture in the country. The chapter, thus, contributes to the development of a critical-historical examination of the political discourses that have developed around notions of 'access', 'participation' and 'engagement' within postwar England. At the centre of Belfiore's analysis is the way in which these notions, and the perceived resulting personal and social benefits, have been articulated and embodied in cultural policies, and the repercussions of a persisting tension between the two key declared aims of British arts policy: access and excellence (Belfiore 2019).

Part One concludes with Kerrie Schaefer's contribution in Chapter 5, a case study of the emergence and development of MED Theatre, a community-based theatre organisation in Dartmoor, a rural area in the south west of England. The chapter charts and discusses the way in which MED Theatre's work represents a reaction to post-war practices of conservation management of the National Park located in the area, which tended to understand the landscape of Dartmoor primarily as a natural environment, In reaction to this view, the chapter looks at how, through community-based theatre, an alternative, and more nuanced understanding of Dartmoor as both a cultural and an ecological landscape was able to emerge. This was possible through a process that ensures that control over the devising of the performance remains at all times with local Dartmoor people themselves, rather than external, professional elites. This 
case study leads Schaefer to consider how a recovery of the concepts of 'community' and 'cultural democracy' might revitalise long-standing British cultural policy debates and thus strengthen political, economic and cultural democracy in the UK (Schaefer 2019).

\subsection{Culture and Governance}

The chapters in this section examine the historical articulation of cultural value and participation through the structures of government. Here the interest focuses on the ways in which state cultural policies and programmes are developed and applied. The chapters in this section are thus interested in the intention of particular cultural policies, and crucially these chapters are also focused on the actual effects of cultural policies. In both of these respects the longer view provided by applying an historical lens allows an understanding of the ways in which the intended and unintended effects of cultural policies apply beyond the realm of culture and into the realms of the civic and the social.

The nineteenth century is a key moment for the 'multiplication of culture's utility' (Bennett 1995) where the rise of the Chartist movement, the extension of the suffrage, and the need to 'civilise' the urban poor led to the development of cultural institutions, especially libraries and museums, in order to provide 'rational recreation'. The development of public parks too was part of this utilisation of culture and (certain types of) recreation by governments as a strategy for regulating populations through the provision of healthy and 'rational' recreation. In Chapter six, Gilmore and Doyle consider the history of public parks and their management in Manchester and Salford from the 1830s to the mid-twentieth century. They analyse how the design and administration of these spaces contributed to strategies for the regulation and improvement of urban populations. In addition, they show how the development of such spaces also provided a venue for a wide variety of forms of everyday participation. 
Thus, they conclude that 'parks offer opportunities for the articulation and negotiation of cultural tastes and values across different socio-economic classes, alongside popular forms of participation in arts, culture and leisure' (Gilmore and Doyle 2019).

The 1980s and 1990s were another distinctive period for the use of culture to effect particular governmental outcomes. In the United Kingdom and also internationally governments were using culture as a tool to effect 'development' articulated in cultural, economic and social terms. Thus, UNESCO as part of its activities for the World Decade for Cultural Development (1988-1997) identified cultural development as a key objective of international policy. The Commission argued that an exclusive focus on economic development had led to a range of social, cultural, and economic problems around the world, and had 'given rise to cultural tensions in many societies' (1996, p. 7). To address these pressing international policy issues, the Commission argued that 'there was a need to transcend economics, without abandoning it' (ibid.). In this context the idea of cultural development was introduced as a way of balancing cultural and economic policy objectives. The economist David Throsby (1997, p. 33 and 1995) has argued that policy determination based solely on fiscal objectives is misled. This is especially evident in the area of cultural policy that should, he suggests, encompass, simultaneously, community demands for non-material well-being, intergenerational equity (that is, the distribution and preservation of resources for future generations), and the interdependence of economic and cultural variables. According to Throsby, these are the conditions for a 'culturally sustainable development' (1997, p. 33 and 1995). In response to arguments like Throsby's, the focus of the cultural development agenda of governments increasingly grafted notions of 'development' and 'sustainability' to the relations between communities and culture.

As part of the cultural development agenda, culture has been used in the context of place-making and urban regeneration projects around the world. 'Culture-led regeneration' 
developments are frequently cited and have become almost shorthand for evidence of successful economic development through cultural investment (Gibson 2013). However, analyses of large-scale cultural investment in such regeneration developments very rarely take account of the interaction between local cultural structures and national cultural programmes. In Chapter seven, Gibson argues for an analysis of the impact of cultural policy via a lens which understands locations as cultural ecosystems. She characterises these ecosystems as grounded in the ways in which historically specific forms of cultural participation and practice interact with local and national cultural policies and programmes. In explicating the influence of local forms of cultural practice and participation, she makes an argument for a cultural policy grounded within the vernacular cultural practices of place as best able to facilitate cultural participation and practice in a way that develops and supports cultural and social ecosystems (Gibson 2019).

Tools for the assessment of the effects of policy are most usually also tools for the construction and assessment of populations (Hacking 1982). The Taking Part Survey is the UK government's flagship research instrument for cultural policy appraisal. In Chapter eight Bunting, Gilmore and Miles examine the historical emergence and significance of Taking Part, using the accounts of civil servants, researchers and policy makers involved in its development to unpack and expose the underlying narrative of the survey itself. Drawing on approaches from cultural sociology, cultural policy studies, and science and technology studies, they counter the official presentation of Taking Part as a neutral technocratic tool for evidence generation. In its place, they reveal the complex social and political life of the participation survey as an expression of a particular set of organisational histories and cultures, arguing that this form of evaluation measure has been complicit in a process that has worked to restrict democratic accountability and to reinforce narrow understandings of participation in cultural policy (Bunting, Gilmore and Miles 2019). 


\subsection{Conclusion}

One of the guiding principles at the core of the UEP project's intellectual and methodological approach was the interconnecting of academic research with different forms of expertise and practice-based knowledge to be found within the policy and practice communities. Insights from our numerous project partners and stakeholders was sought from the outset to help the research team develop the topic guide used for interviews across ecosystems. Stakeholders' expertise in illuminating, informing and complementing academic perspectives was central to the team's ambition that UEP's research outputs should combine rigorous, quality research with genuinely relevant and helpful contribution to fresh thinking in both policy and practice ${ }^{4}$. In light of this intellectual positioning of the project as a whole, we wanted to ensure that in this volume too, the practitioner perspective was present and recognised. The book therefore concludes with an Afterword by Peter Stark, a veteran of local arts administration and policy in the North East of England, whose distinguished track record in the field was acknowledged with the award of an OBE in 1990. Stark played a pivotal role in the establishment of arts organisations big and small, including the capital projects that led to the institution of Baltic, Sage Gateshead and Millennium Bridge, in the heyday of culture-led regeneration in Newcastle/Gateshead. Having been a key protagonist of the recent history of UK place-based policies for cultural development (as shown in the account of policy development in Gateshead in Gibson's chapter), Stark offers a distinctly personal reflection on the material in the book and its resonance with decades of professional experience locally, nationally and internationally. It seems fitting for the book to end with an impassionate affirmation of the importance that awareness of history - both more and less recent - has in making sense of

\footnotetext{
${ }^{4}$ For more on UEP and the question of the research-policy-practice nexus, see Belfiore (2016); for examples of UEP scholarship that has led to fresh thinking on policy and practice, see Gibson and Edwards (2016), Gilmore (2017), Miles and Ebrey (2017).
} 
today's policy priorities and of the lived reality of those involved in making and implementing policy decisions.

We conclude this introduction with some thoughts on the interdisciplinary nature of the scholarship gathered in this volume. Much in the same way that the UEP project was predicated on recognising the value and contribution of practice-based knowledge to the exploration of cultural participation and the stakes that are attached to it (and, thus, to the reconfiguration of accepted notions of cultural value), the project has also been driven by the belief that explorations of complex cultural, social and policy issues require an inter- and multidisciplinary approach. The authors of the essays in this collection weave both humanities and social sciences approaches and methods in their research, and one of the ostensibly more innovative features of the UEP project is precisely the ways in which it rejected the prevalent 'knowledge regimes' within cultural policy. In Campbell and Pedersen's (2011: 167) definition, '[k]nowledge regimes are sets of actors, organizations, and institutions that produce and disseminate policy ideas that affect how policy-making and production regimes are organized and operate in the first place'. As Bunting, Gilmore and Miles argue in Chapter eight, in the policy sphere, prevalent knowledge regimes display a predilection for quantitative data and methods drawn from the empirical social sciences, at the expense of arts and humanities approaches, which are seen as having less to contribute to policy sensitive research (Belfiore and Bennett 2010). In line with the UEP project's interdisciplinary methodological stance, and its rejection of a hierarchy of discipline and methods in cultural policy studies, the book highlights the contribution that arts and humanities - and particularly historical research make, in allowing us to understand the relationships between culture and power in cultural policy and programmes, and what is at stake in everyday forms of participation (both for individuals and communities). 
This edited collection represents a proud statement of arts and humanities' contribution, alongside and on a par with social sciences methods (both quantitative and qualitative), to studies of participation and cultural values. As researchers who also teach on university programmes aimed at future arts and museum professionals, we have witnessed the significance of an education infused with arts and humanities perspectives and methods in giving future practitioners a historical and theoretical understanding of the issues faced by the sector. This knowledge allows them a critical perspective on how cultural institutions and funding mechanisms operate and on their own practice within them (Gibson 2008). At the present time, which sees arts and humanities scholarship and study under attack for being 'useless' and irrelevant (Belfiore 2013), we hope this collection of essays will offer a powerful rebuttal, and a compelling demonstration of the benefits that a humanities and historical perspective brings to the examination of live policy problems. 


\section{Bibliography}

Arts Council England. (2014). The value of arts and culture to people and society: an evidence review. Arts Council England. https:/www.artscouncil.org.uk/sites/default/files/downloadfile/Value arts culture evidence review.pdf. Accessed 5th July 2019.

Arts Council England. (2014). Understanding the value and impacts of cultural experiences. Arts Council England. https:/www.artscouncil.org.uk/sites/default/files/downloadfile/Understanding the Value_and_Impacts_of_Cultural_Experiences.pdf. Accessed 5th July $\underline{2019}$.

Belfiore, E. (2019) 'From CEMA to the Arts Council: Cultural authority, participation and the question of 'value' in early post-war Britain'. In Belfiore, E. and Gibson, L. eds., Histories of Cultural Participation, Value and Governance, London: Palgrave.

Belfiore, E. (2016). 'Cultural policy research in the real world: curating "impact", facilitating "enlightenment"”. Cultural Trends, 25(3), 205-216.

Belfiore, E. (2013). 'The 'Rhetoric of Gloom' vs. the Discourse of Impact in the Humanities: Stuck in a Deadlock?. In Belfiore, E. and Upchurch, A. (eds.) Humanities in the twenty-first century, London: Palgrave, 17-43.

Belfiore, E., \& Bennett, O. (2010). 'Beyond the "Toolkit Approach": arts impact evaluation research and the realities of cultural policy-making'. Journal for Cultural Research, 14(2), 121-142.

Belfiore, E., \& Bennett, O. (2008). The Social Impact of the Arts: An intellectual history. London: Palgrave. 
Bennett, O. (2005). 'Beyond machinery: The cultural policies of Matthew Arnold'. History of political economy, 37:3, 455-482.

Bennett, T. (1995). 'The Multiplication of Culture's Utility'. Critical Inquiry. 21: 4, 861-889.

Bronowski, J. and Mazkisch, B. (1960) The Western Intellectual Tradition: From Leonardo to Hegel, London: Hutchinson.

Bunting, C., Gilmore, A. and Miles, A. (2019). 'Calling participation to account: Taking part in the politics of method'. In Belfiore, E. and Gibson, L. eds., Histories of Cultural Participation, Value and Governance, London: Palgrave.

Campbell, J. L., \& Pedersen, O. K. (2011). 'Knowledge regimes and comparative political economy’. In Béland, D. and Cox R. H. (eds.) Ideas And Politics In Social Science Research, Oxford: Oxford University Press, 167-190.

Crossick, G., and \& Kaszynska, P. (2016). Understanding the value of arts \& culture :The AHRC Cultural Value Project, Arts and Humanities Research Council. https://ahrc.ukri.org/documents/publications/cultural-value-project-final-report/. Accessed $5^{\text {th }}$ July 2019.

Gibson, L. (2019). 'Cultural Ecologies: Policy, Participation and Practices'. In Belfiore, E. and Gibson, L. eds., Histories of Cultural Participation, Value and Governance, London: Palgrave.

Gibson, L. (2013). 'Piazzas or Stadiums: Towards an alternative account of museums in cultural and urban development'. Museum Worlds: Advances in Research, 1(1), 101-112.

Gibson, L. (2008). 'In defence of instrumentality'. Cultural Trends, 17(4), 247-257.

Gibson, L., \& Edwards, D. (2016). 'Facilitated participation: cultural value, risk and the agency of young people in care'. Cultural Trends, 25(3), 194-204. 
Gilmore, A. (2017). 'The park and the commons: vernacular spaces for everyday participation and cultural value'. Cultural Trends, 26(1), 34-46.

Gilmore, A. and Doyle, P. (2019). 'Histories of public parks in Manchester and Salford and their role in cultural policies for everyday participation'. In Belfiore, E. and Gibson, L. eds., Histories of Cultural Participation, Value and Governance, London: Palgrave.

Hacking, I. (1982). 'Biopower and the Avalanche of Printed Numbers'. Humanities in Society. 5:279-295.

James, F. (2019). 'Cultural participation and the place of history: a case study of Peterborough societies, past and present'. In Belfiore, E. and Gibson, L. eds., Histories of Cultural Participation, Value and Governance, London: Palgrave.

Miles, A., and Ebrey, J. (2017). 'The village in the city: participation and cultural value on the urban periphery'. Cultural Trends, 26(1), 58-69.

Miles, A., \& Gibson, L. (2016). 'Everyday participation and cultural value'. Cultural Trends, 25(3), 151-157.

Miles, A., and Sullivan, A. (2012). 'Understanding participation in culture and sport: mixing methods, reordering knowledges'. Cultural Trends, 21(4), 311-324.

Milling, J. (2019). 'Valuing Cultural Participation: The Usefulness of the Eighteenth-Century Stage'. In Belfiore, E. and Gibson, L. eds., Histories of Cultural Participation, Value and Governance, London: Palgrave.

Neelands, J., Belfiore, E., Firth, C., Hart, N., Perrin, L., Brock, S., Holdaway, D., and Woddis, J. (2015) Enriching Britain: Culture, Creativity and Growth: The 2015 Report by the Warwick Commission on the Future of Cultural Value, University of Warwick. 
https://warwick.ac.uk/research/warwickcommission/futureculture/finalreport/warwick comm ission_final_report.pdf. Accessed 5th July 2019.

Schaefer, K. (2019). 'Enacting Community on Dartmoor: MED Theatre's Badgerland: A Dartmoor Comedy (2015) and the spatial praxis of community performance within a conservation zone'. In Belfiore, E. and Gibson, L. eds., Histories of Cultural Participation, Value and Governance, London: Palgrave.

Stark, P. (2019). 'An Afterword'. In Belfiore, E. and Gibson, L. eds., Histories of Cultural Participation, Value and Governance, London: Palgrave.

Throsby, D. (1997). 'The relationship between cultural and economic policy', Culture and Policy, 8, 1, 25-36.

Throsby, D. (1995). 'Culture, economics and sustainability', Journal of Cultural Economics, 19, 3, 199-203.

UNESCO World Commission on Culture and Development. (1996). Our Creative Diversity, UNESCO, Paris.

Williams, R. (1990 [1958]). Culture and Society, London: Chatto \& Windus. 